This is a self-archived - parallel published version of this article in the publication archive of the University of Vaasa. It might differ from the original.

\title{
Globalisation and Human Resource Management
}

Author(s): Brewster, Chris; Smale, Adam; Mayrhofer, Wolfgang

Title: $\quad$ Globalisation and Human Resource Management

Year: $\quad 2017$

Version: Accepted manuscript

Copyright (C)2017 Edward Elgar Publishing Ltd. This is a draft chapter. The final version is available in A Research Agenda for Human Resource Management edited by Paul Sparrow and Cary L. Cooper, published in 2017, Edward Elgar Publishing Ltd https://doi.org/10.4337/9781785362965.00017. The material cannot be used for any other purpose without further permission of the publisher, and is for private use only.

\section{Please cite the original version:}

Brewster, C., Smale, A., \& Mayrhofer, W., (2017). Globalisation and Human Resource Management. In: P. Sparrow, \& C.L. Cooper (eds), A Research Agenda for Human Resource Man agement (pp. 201-218). Edward Elgar Publishing Ltd. https://doi.org/10.4337/9781785362965.00017. 


\section{Chapter 12}

\section{Globalisation and Human Resource Management}

Chris Brewster, Adam Smale and Wolfgang Mayrhofer

(C) 2017 Chris Brewster, Adam Smale and Wolfgang Mayrhofer. All rights reserved.

“[...] globalisation/regionalisation, migration and reverse migration (also referred to as 'brain circulation'), the ascendancy of emerging markets, the demand for people with a global mindset, and the worldwide war for talent have brought about fundamental changes to the nature, magnitude, and raison d'etre for human resource management (HRM) in a global context." (Tung, 2016: 142)

\subsection{Introduction: Globalisation and HRM}

Globalisation has obvious implications for HRM. Beer and his colleagues, in one of the earliest scholarly analyses of HRM, paid considerable attention to the influence of context (Beer, Spector, Lawrence, Quinn, \& Walton, 1984). However, most HRM research since that time has been conducted in single countries. The international HRM (IHRM) literature has eschewed this narrow focus and integrated the international context in various ways. Here we examine globalisation in connection with two of the main streams of research in IHRM (we exclude expatriation and mobility): comparative HRM (CHRM), examining the commonalities and differences in HRM between regions and nations; and HRM in multinational enterprises (MNEs), examining the HRM policies and practices of organisations operating across national boundaries. 
In this final chapter of the book, we first outline the significance of globalisation for HRM and then briefly review how it has been incorporated into each of the two streams. We use the notions of context, time and process to structure the review. The final section sets out a research agenda and examines how synergies can be created from bridging the two streams.

Given what is happening in the world of business and politics, we suggest that an understanding of HRM increasingly needs to take an international and comparative view. Discussions of globalisation are as lively in the management literature as they are in the political and cultural literature. Globalisation is arguably a factor for all organisations. This is obviously true for MNCs, but smaller organisations in most countries (particularly in the European Union) are also impacted by competition from foreign organisations. In the public sector, there are not only the traditional diplomatic agencies that governments have (and staff) in other countries, but also the emergence of governmental and non-governmental international organisations such as the United Nations or the Red Cross. Increasingly, government departments are working with other agencies across their region or across the world. An increased knowledge about the specifics of management across borders, including knowledge of how HRM issues are handled in various countries (Dickmann, Brewster, \& Sparrow, 2008) has become a prominent issue for social scientists as it has become a key issue for all kinds of managers.

As international integration and the growing interconnectedness of business increases (Dunning, 2004 (1993)), globalisation may act to strengthen the specific advantage of particular locations or subsidiaries (Rugman \& Verbeke, 2001) or it may act to increase standardisation around the globe (Kostova \& Roth, 2002). This standardisation may take place between regions, countries or country clusters, as HRM policies diffuse around the world, or it may take place within MNEs, as they attempt to harmonise HRM practices and ensure local responsiveness as well as consistency across their foreign operations (Evans, Pucik, \& Björkman, 2017 (in press)). More generally, this speaks to the convergence and divergence of 
HRM at the global level as well as the different consequences of globalisation for HRM in different countries and regions - classical issues in both the CHRM and HRM in MNEs literatures.

Globalisation, an all-pervasive phenomenon with ample coverage in the research literature (e.g., Michie, 2003), has given momentum to heated debate about long-term developments towards convergence or divergence at the macro level of nation states and the meso level of organisational practices. The 'globalisation thesis' proposes that countries become increasingly similar (a convergence thesis) with respect to their tastes, behavioural patterns, cultural values and governance systems due to drivers such as patterns of industrialisation, trade barrier diminution, globalised media, homogeneous consumer demand, digitalisation, financial markets, and information and capital flows.

Arguably the most elaborate view comes from the world-polity approach within sociological neo-institutionalism (for an overview see Greenwood, Oliver, Suddaby, \& Sahlin, 2008). It argues that, especially since 1945, Western cultural patterns and institutions dominate global developments so that core individual and collective actors, including organisations and nation states, are subject to isomorphic pressures to follow the Western model of rationalisation (Drori, Meyer, \& Hwang, 2006). Underlying these considerations is the view that the role of nation states will further decrease (Ohmae, 1995) and that a world-society (Krücken \& Drori, 2009) emerges which is the primary locus of rationalisation.

This does not necessarily mean complete uniformity. There is room for local variation and distinctiveness. For instance, research on the translation of business and political practices across cultural and national borders emphasises that both freedom for social action as well as isomorphic pressure co-exist (see, e.g. Czarniawska \& Sevón, 2005). As practices travel across the world and become institutionalised, they are edited and customised to specific contextual settings. 
Nevertheless, the convergence thesis has not remained uncontested. The contesters come from the cultural as well as the institutional camps. The cultural view emphasises that national and regional cultures are the result of substantial differences in norms, values and belief systems (Hofstede, Hofstede, \& Minkov, 2010; House, Hanges, Javidan, Dorfman, \& Gupta, 2004). This makes convergence at all levels highly unlikely. There is a substantial body of literature showing that management practices differ enormously across countries and cultures and that there are no convincing reasons why these differences should vanish in the future.

From an institutional perspective, there are also significant doubts about converging tendencies. Theories of comparative institutionalism in the varieties of capitalism literature (e.g., Hall \& Soskice, 2001; Whitley, 1999) argue that given the differences in institutional arrangements at the national level and their relative inertia, it is hard to see existing differences between systems of economic organisation disappear. Whitley (1999) argues that "[n]ation states constitute the prevalent arena in which social and political competition is decided in industrial capitalist societies" (19). This suggests differences, not convergence, and limits to globalisation (Guillén, 2001).

This global/ local tension underlies not only international business in general, but also extensive research in the field of IHRM. A much-cited article from the 1990s (Rosenzweig \& Nohria, 1994) points out that this tension is of heightened relevance for HRM since of all the management functions, HRM is the most sensitive to local conditions. So globalisation, via both convergent and divergent forces, impacts HRM within organisations, MNEs in particular, but HRM also remains stubbornly rooted in its own national context. Among others, this has given rise to research along two streams within IHRM - comparative HRM and HRM in MNEs. We briefly review each in turn. To do so we adopt the concepts of context, process and time, familiar from the business strategy literature to structure the discussion (Brewster, 
Mayrhofer, \& Smale, 2016). We detail how each of these concepts has been used in each of the streams below.

\subsection{Comparative HRM}

CHRM examines HRM between countries or between clusters of countries or geographical regions (Brewster \& Mayrhofer, 2012). In some contrast to the tenets of the 'globalisation thesis', this literature has identified persistent commonalities and differences between countries in the way they conceive HRM, the way they evaluate it and the way that HRM is practiced.

\subsubsection{Context}

Context in the general business literature is often captured by the notion of contingency, refers to the differences in management processes created by the size of the business, the sector(s) in which it operates and the situation in which it is embedded. It is the last of these, particularly geographic context, that is by definition a key issue in the CHRM stream. As discussed above, theories underlying CHRM are based around the impact of cultural or institutional differences between nations. Culturalists argue that there are deep-rooted differences in values and beliefs between nations (Hofstede et al., 2010; House et al., 2004) and these are inevitably reflected in the way people are managed at work, e.g. in terms of leadership (Moran, Harris, \& Moran, 2011) or career management (Shen et al., 2015). Institutionalists on the other hand believe that it is the structures and mechanisms of social order that support and constrain the behaviour of businesses. Synthesising and developing these ideas, the comparative capitalisms literature (Hall \& Soskice, 2001; Whitley, 1999) suggest that the elements of the system external to the business tend to be reflected in internal relationships - or HRM. 
In CHRM research, contextual explanations drawing upon institutionalism seem to have taken over from those based on cultural differences. This may reflect the critique of the cultural literature (Avloniti \& Filippaios, 2014; Gerhart \& Fang, 2005) or simply that each culture contains a more or less normal distribution of people who fit the stereotype in question and organisations can select or avoid people 'typical' of that culture (Vaiman \& Brewster, 2015). There is much less they can do to avoid the effects of institutions.

The overwhelming conclusion within the CHRM stream is that context matters, since patterns and models of HRM are consistently shown to vary between countries and institutional contexts (e.g., Wood, Brewster, \& Brookes, 2014; Morley, Heraty, \& Michailova, 2009). Much of the data coming from the on-going Cranet (www.cranet.org) surveys, studies have identified clear differences in HRM practices between countries ranging from the professionalism of the HR function (Farndale, 2005) to compensation practices (Lowe, Milliman, De Cieri, \& Dowling, 2002), to training (Goergen, Brewster, Wood, \& Wilkinson, 2012).

\subsubsection{Time}

In organisation theory, time has had a prominent place in calls for better theory building (e.g. Mitchell \& James, 2001). In CHRM this is focused on the debates around convergence. Time is embedded in questions concerning whether differences between countries and regions are increasing, static or decreasing, and calls for longitudinal analyses. Cranet, which has collected 25 years of broadly representative country data at roughly five-year time intervals, has made some advances in this regard.

Since time is so important to the CHRM stream (since if country differences are decreasing there is less value in studying them), defining constructs such as convergence is an appropriate starting point (Mayrhofer, Müller-Camen, Ledolter, Strunk, \& Erten, 2002). Directional 
convergence points towards similar trends. Even if the same trend is apparent in many countries, different starting points and different rates of change may mean that countries remain as far apart as ever or even diverge further. For final convergence, countries would have to become more alike in the way that they manage their HRM over time.

However, the empirical evidence shows little evidence of final convergence. Whether based on cultural or institutional analyses, or on a combination of the two, the research has tended to reveal continuing differentiation. While we see instances of directional convergence/ similarity (e.g. Mayrhofer, Brewster, Morley, \& Ledolter, 2011), no convincing case for final convergence has been made.

\subsubsection{Process}

Process, or the means and mechanisms through which management operates, is a surprisingly neglected perspective in the study of IHRM:

"... the literature has presented only limited accounts of what actually happens in the process of constructing and negotiating HR [M] systems in the context of so many potentially conflicting institutional rationales" (Rupidara \& McGraw, 2011: 175).

Indeed, it is argued that since 'Western' cultural patterns and institutions dominate global developments, actors including organisations and countries are subject to strong isomorphic pressures to follow that model (Drori et al., 2006). So how does convergence and divergence occur? How do these pressures manifest themselves and how do models of HRM become institutionalised?

Both cultural and institutional theories have been criticised for being rather static (e.g. Oliver, 1991) and for a lack of clarity about how the broader social context impacts HRM (Edwards \& Kuruvilla, 2005b). Neither allow much room for agency - for individuals and organisations to 
'buck the trends'. Given the centrality of the convergence/ divergence debate within the CHRM stream and the corresponding significance of time in providing answers, a lack of theory and in-depth empirical examination into the processes and mechanisms of convergence and divergence can be seen as a serious shortcoming. We return to this and other issues in the agenda for future research.

\subsection{HRM in Multinational Enterprises (MNEs)}

The stream of HRM in MNEs deals with HRM issues that businesses face when they operate across national borders, unified in their attempts to provide answers to the main overriding question of how people are managed in MNEs and with what outcomes (Björkman \& Welch, 2015). Based on research published in top management journals, Werner (2002) summarised the territory of international management research as comprising the following key areas:

- Global business environment

- Internationalisation

- Entry mode decisions

- Foreign direct investment (FDI)

- International exchange

- International joint ventures

- Strategic alliances and networks

- Transfer of knowledge

- Multinational enterprises (MNEs)/ multinational corporations (MNCs)

- Subsidiary-HQ relations 
- Subsidiary and multinational team management

- Expatriate management

Under this broad umbrella, the dominant research themes within HRM in MNEs can be seen as relating to the management of MNE subsidiaries and knowledge transfer. More specifically, its focus has been on the extent of, and processes involved in, the transfer of HRM practices between MNE headquarters and their foreign subsidiaries (Welch \& Björkman, 2014). This has typically been explained as contingent upon a complex interaction of factors relating to the home- and host-country contexts, the strategy and structure of the global corporation and the subsidiary, and the nature of the headquarters-subsidiary relationship (Edwards \& Kuruvilla, 2005a).

\subsubsection{Context}

Context in the HRM in MNEs stream is often framed as a tension, or duality, between HRM standardisation and the constraints imposed by the local environment (Ferner et al., 2011), more specifically about the external and internal variables that explain why MNEs may 'desire' to standardise/transfer HRM, and why this might not be 'feasible' (Dickmann, 2003). There is an implicit assumption in much of this research that the MNE's desire to standardise their HRM is restricted by local contextual constraints that require them to compromise. The reverse scenario, i.e. how the local contextual norms and arrangements regarding HRM is influenced by MNEs and MNE subsidiaries, is much less often researched even though it seems likely that, especially in societies where institutions are new or weak, MNEs may have considerable power to influence institutions in their favour (Thite, Wilkinson, \& Shah, 2012; Welch \& Björkman, 2015). There has equally been a dearth of literature examining contextual effects at a regional level, either externally in terms of regional exogenous effects or internally in terms 
of regional MNE structures (e.g. regional HQ), despite the regional nature of international business (Rugman \& Oh, 2013) and the tendency for larger MNEs to regionalise their operations.

Departing from the dominant headquarters' view of HRM in MNEs, research adopting the subsidiary perspective and examining the contextual antecedents of reverse HRM transfer has also attracted growing attention. Context in this sub-domain is analysed from the host-country perspective, looking at conditions under which foreign subsidiaries, usually from institutionally strong host-country settings, are capable of reverse transferring HRM practices to headquarters (Edwards \& Tempel, 2010), as well as laterally to other MNE subsidiaries (Edwards, SanchezMangas, Bélanger, \& McDonnell, 2015).

\subsubsection{Time}

Time has received much less attention within the HRM in MNEs stream. A large proportion of research in this stream is quantitative (Welch \& Björkman, 2015), based on cross-sectional data and using predominantly subjective and varying measures/ classifications of HRM practices. This has rendered it almost impossible to make inferences about patterns of standardisation or differentiation over time. Whilst some isolated studies comparing HRM in subsidiaries has suggested that there is a 'dominance' of (US-style) HRM 'best practice' that is creating an inexorable move towards convergence of practices across foreign subsidiaries (Pudelko \& Harzing, 2007), much of this research is not longitudinal in design (cf. Björkman, Smale, Sumelius, Suutari, \& Lu, 2008).

However, there has been some insightful, longitudinal-type, qualitative work in the form of case studies. These have revealed the important role that power relations and micro-political processes play in determining the use and effectiveness of different HRM control mechanisms 
over time (e.g., Ferner, 2000) and the influence of strong local cultures (Dixon, Day, \& Brewster, 2014). They have also contributed a more dynamic view of HRM transfer by demonstrating that standardisation should be seen as fluctuating and subject to continual negotiation between parent and subsidiary. Whilst case studies can facilitate the study of HRM developments over time in a potentially nuanced fashion, one could still argue that case studies are inferior when it comes to identifying overall trends or showing representative change over time.

\subsubsection{Process}

Process perspectives in HRM in MNEs have only quite recently started to attract serious theoretical and empirical attention. A possible explanation for this lack of focus on issues of process, apart from the disproportionately high number of quantitative studies, is the dominance of contingency models (DeCieri \& Dowling, 2012). Nevertheless, interest has grown in part in response to a broader critique that a lack of focus on the processes through which HRM practices are created and developed is a shortcoming in the general HRM literature (Paauwe, 2004). Process is, in a variety of ways, gradually infiltrating the HRM in MNEs stream. For instance, we are being encouraged to conceive of HRM systems as comprising different process features such as validity, visibility, consensus, and justice that send signals that are interpreted heterogeneously by individuals, which in turn leads to strong/weak HRM climates (Bowen \& Ostroff, 2004).

This 'process school' emphasises the role of key actors at higher levels (Rupidara \& McGraw, 2011) as well as the role of psychological processes at the individual level through which employees attach meaning to HRM (Sanders, Shipton, \& Gomes, 2014). There have been similar calls for actor-centric research into the HR function itself: who the key actors are and 
what their roles actually are in HRM development processes (Welch \& Welch, 2012). Drawing on the strategy-as-practice perspective in the strategy literature, it is suggested that a similar focus on how HRM practices, practitioners in a broad sense and praxis interact will advance our understanding of the processes behind how people-related decisions within organisations are made, implemented and enacted (Björkman, Ehrnrooth, Mäkelä, Smale, \& Sumelius, 2014).

\subsection{A future research agenda for International HRM}

We suggest that a future research agenda for international HRM should take account of globalisation in four different but inter-related respects: paying more attention to context, process, time and the potential synergies between the comparative HRM and HRM in MNEs streams.

\subsubsection{Context.}

A fruitful avenue of future research for CHRM in terms of context involves researching HRM in a wider range of countries and conducting more fine-grained cross-county comparisons. Most HRM research, and most IHRM research, has been conducted in the WEIRD - western, educated, industrialised, rich, democratic - countries (Henrich, Heine, \& Norenzayan, 2010). What we know so far covers a minority of the world's countries, with limited data from countries outside of the Global North in particular, though there are welcome developments in the range of countries being studied (see e.g. Budhwar \& Mellahi, 2006; Dessler \& Tan, 2009; Dowling \& Donnelly, 2013).

Research within HRM in MNEs has focused on the effects of external contextual determinants on MNE headquarters' and subsidiary HRM practices. How MNEs influence local HRM 
practice - for example, through the deployment of various power and political resources - is a significant research gap (Welch \& Björkman, 2015). Arguably a crucial impulse and motor of development, in particular in the so-called developing economies, MNEs can play an important role in spreading HRM innovations. To the best of our knowledge, however, there is extremely little analysis on whether different degrees of MNE presence in various countries have systematic effects on developments within these countries, or whether these effects are similar in other contexts. Specifically, we know little about the effect of foreign MNEs on the institutional environment governing HRM in a country and, of particular importance with regard to the convergence/ divergence debate, the long-term effect on HRM in these countries, e.g. the emergence of a standardised national model. The research on CHRM, on the other hand, has taken little account of the internal context of MNEs and how that impacts the spread or variation of HRM policies and practices.

Context is a highly diverse concept used, among others, by linguists, anthropologists, and political scientists. Especially in countries such as Nepal, Pakistan, Angola, or Libya with 'difficult' or 'extraordinary' contextual situations in terms of geography, language diversity, political stability, intra-national relationships between different groups or tribes, we understand very little about how HRM unfolds and develops in such settings. For instance, we know next to nothing about whether MNEs choose similar HRM strategies to cope with the situation in such countries and whether these strategies change or stay stable over time. Our understanding of what happens with regard to convergence/divergence would deepen were we to apply a more differentiated view of what context means and look at areas currently 'off the map' for the most part.

\subsubsection{Process}


Process, in particular the various ways in which HRM is diffused, negotiated, (de)institutionalised, perceived and enacted, holds substantial potential in deepening our understanding about convergence / divergence at the cross-national level as well as standardisation/ localisation at the firm level. Firstly, this necessitates stronger theoretical approaches for analysing the dynamics behind convergence/divergence and the spread of HRM policies and practices, with more in-depth discussions about theoretical discourses. In line with a renewed interest in actor-centric viewpoints in literatures about strategy (Eisenhardt, Furr, \& Bingham, 2010) and institutional thinking (Powell \& Colyvas, 2010) we call for research that incorporates the roles of key actors in these processes. More detailed studies of the roles and activities of key actors at various levels within the MNE will clarify the dynamic interactions between MNE actors and their context in shaping HRM practices (Rupidara \& McGraw, 2011). This will also serve to complement theoretical insights from neo-institutionalism with those based around agency, power and politics in revealing the complex dynamics of the contested institutional terrain. We support a broader conceptualisation of 'practitioners' (Björkman et al., 2014) or stakeholders (Beer, Boselie, \& Brewster, 2015) to include key individual and collective actors both internal and external to the MNE. The CHRM literature could similarly benefit from the addition of an actor perspective and bring in hereto neglected actors (e.g. business schools, HR professional associations, consultants, HR gurus, policy makers, lobbying groups) into the empirical realm. In short, if our understanding of HRM convergence and divergence processes is to progress beyond attempts at explaining observed similarities and differences between organisational practices, we need more theoretically-grounded research and more innovative research designs that directly tackle issues of process within and across levels of analysis.

\subsubsection{Time}


Time should be more central to empirical research efforts within both streams - within CHRM due to convergence/divergence lying at the heart of its main research question; and within HRM in MNEs due to its conspicuous absence - even in areas such as expatriate adjustment where time spent in a country has an clear but non-straightforward impact (Hippler, Brewster, \& Haslberger, 2015).

This almost inevitably means more longitudinal research. Besides serving as a stronger foundation for inferences about causality - an issue that afflicts a substantial proportion of the IHRM literature - it also allows studies to capture how change occurs, the speed and direction of change and whether the rate of change is constant. We suggest the more targeted use of and improvements to existing data. For instance, in addition to HRM-specific databases such as Cranet, we believe there is also a lot of potential in using other available data such as the European Working Condition Survey - two waves of data from 2005 and 2010 are available with data from the sixth round in 2015 being made publicly available soon.

We would simultaneously call for a careful treatment of time in such future studies. For instance, time spans should be related to the context they denote. Three years in a comparatively stable period, e.g. 1982-1985, do not equal three years in a time of dramatic global change, e.g. 2007-2010. Hence, assigning qualitative elements to time spans and taking into account sequential effects could bring valuable insights into the dynamics of convergence or divergence. There is also scope to complement existing 'trend' studies with empirical studies that rely on matched samples. Practicalities may mean that these studies have to make certain concessions in terms of smaller samples, fewer countries and shorter time spans, but they will bring deeper understanding of how, when and why convergence/ divergence occurs. In terms of HRM in MNEs, this kind of research might shed more light on HRM-related decisions during the internationalisation process and the factors leading up to more mature MNEs to go 
through 'pendulum swings' in terms of their periodic focus on HRM standardisation and localisation (Farndale et al., 2010; Evans, Pucik, \& Björkman, 2011).

\subsection{Conclusions: Synergies between CHRM and HRM in MNEs}

Synergies are clear from much of the preceding discussion. CHRM and HRM in MNEs streams would each be improved through better acknowledgement of research in the other tradition and via greater dialogue and cross-fertilisation. Context is the topic of several discourses across a number of disciplines, reaching far beyond management or organisation studies. Against this backdrop, it seems especially fruitful to exploit these discourses in the narrower realms of international HRM. Cross-fertilisation can principally be realised through empirical examinations of the processes taking place at the intersections between MNEs and the national/global systems of HRM in which they are embedded. Indeed, it is rare that studies in HRM in MNEs place equal emphasis - either in terms of theory or research design - on MNE headquarters/home-country issues and subsidiary/host-country issues (McDonnell, Lavelle, \& Gunnigle, 2014). The added challenge of data access notwithstanding, such studies are much better placed to draw conclusions about HRM convergence/divergence in ways that can combine and leverage the explanations offered by each of the two streams.

Combining the insights from research in HRM in MNEs and CHRM would deepen our understanding of convergence/ divergence by taking into account the mutual effects between the national and organisational levels. Given the historically greater importance attached to the role of MNEs in this regard, Welch and Björkman (2015) suggest looking to the international business literature for examples of how this could be done. As an example, the neoinstitutionalist school of thought is already established in both streams. Developments within this theoretical discourse have not fully found their way into IHRM discourse, nor been used 
to explain convergence and divergence between countries or standardisation and differentiation within MNEs.

The neo-institutionalist school of thought has produced a number of insights which might usefully inform IHRM research concerning potential mechanisms of standardisation/ convergence. A few examples may suffice, such as an individual director being a member of two or more boards provide an important means for transferring information and know-how between organisations (Shipilov, Greve, \& Rowley, 2010). In HRM, further exploring the role of such interlocks for spreading HRM policies and practices across different organisations and national borders would give us additional insights in the role of social networks in the processes of standardisation/convergence. Proximity plays an important part when looking at how HRM spreads. The relative position of the units of analysis such as organisations or countries between themselves often is operationalised by a variant of proximity such as geographical or cultural proximity. However, other forms of proximity with arguably an equally important role such as social or technological proximity (Knoben \& Oerlemans, 2006) are rarely researched. They could provide a more detailed understanding of how 'closeness' influences standardisation and convergence of HRM across the globe. The discussion on translation and diffusion (Czarniawska \& Sevón, 2005) emphasises analysing the how, why and when of organisational policies and practices spreading across different organisations and countries actually refers to a complicated and multi-faceted process. Far from being a simple 'transfer', the policies and practices are taken apart and re-assembled, with various factors such as political interests, implicit and cultural norms, and legal regulations coming into play, leading to a new 'product'. Again, efforts of standardisation in HRM can hardly be understood properly without such a more in-depth understanding of how processes of translation and travel rather than a mere transfer with minor amendments take place. Neo-institutional thinking allows a coherent view 
of such issues partially addressed in current HRM research and links it with broader organisational phenomena.

Of course, not all of these ideas can be immediately translated into empirical research settings within CHRM or HRM in MNEs. Yet, we do suggest that a more systematic incorporation of these theoretical insights can open up new avenues for making sense of the processes underlying HRM convergence and divergence and standardisation/ differentiation.

\section{References}

Avloniti, A., \& Filippaios, F. (2014). Evaluating the effects of cultural difference on corporate performance: A meta-analysis of the existing literature. International Business Review, 23(3), 660-674.

Beer, M., Boselie, P., \& Brewster, C. (2015). Back to the future: Implications for the field of HRM of the multi-stakeholder perspective proposed 30 years ago. Human Resource Management, 54(3), 427-438.

Beer, M., Spector, B., Lawrence, R., Quinn, M. D., \& Walton, E. (1984). Managing Human Assets: The groundbreaking Harvard Business School program. New York: Free Press.

Björkman, I., Ehrnrooth, M., Mäkelä, K., Smale, A., \& Sumelius, J. (2014). From HRM practices to the practice of HRM: setting a research agenda. Journal of Organizational Effectiveness: People and Performance, 1(2), 122-140.

Björkman, I., Smale, A., Sumelius, J., Suutari, V., \& Lu, Y. (2008). Changes in institutional context and MNC operations in China: Subsidiary HRM practices in 1996 versus 2006. International Business Review, 17(2), 146-158.

Björkman, I., \& Welch, D. (2015). Framing the field of international human resource 
management research. The International Journal of Human Resource Management, 26(2), 136-150.

Bowen, D. E., \& Ostroff, C. (2004). Understanding HRM-firm performance linkages: The role of the "strength" of the HRM system. Academy of Management Review, 29(2), 203221.

Brewster, C., \& Mayrhofer, W. (2012). Handbook of research on comparative human resource management. Cheltenham: Edward Elgar Publishing.

Brewster, C., Mayrhofer, W., \& Smale, A. (2016). Crossing the Streams: HRM in Multinational Enterprises and Comparative HRM. Human Resource Management Review, 26(4): 285-297.

Budhwar, P. S., \& Mellahi, K. (2006). Managing human resources in the Middle East. London: Routledge.

Czarniawska, B., \& Sevón, G. (Eds.). (2005). Global Ideas. How Ideas, Objects and Practices Travel in the Global Economy. Copenhagen: Liber, Copenhagen Business School Press.

DeCieri, H., \& Dowling, P. (2012). Strategic human resource management in multinational enterprises: developments and directions. In G. K. Stahl, I. Björkman, \& S. Morris (Eds.), Handbook of research in international human resource management (2nd ed., pp. 13-35). Cheltenham: Edward Elgar.

Dessler, G., \& Tan, C.-H. (2009). Human Resource Management, An Asian Perspective. Singapore: Pearson Education.

Dickmann, M. (2003). Implementing German HRM abroad: desired, feasible, successful? International Journal of Human Resource Management, 14(2), 265-283. 
Dickmann, M., Brewster, C., \& Sparrow, P. R. (Eds.). (2008). International Human Resource Management: A European Perspective (2 ed.). London: Routledge.

Dixon, S., Day, M., \& Brewster, C. (2014). Changing HRM systems in two Russian oil companies: Western hegemony or Russian spetsifika? . International Journal of Human Resource Management, 25(22), 3134-3156

Dowling, P. J., \& Donnelly, N. (2013). Managing people in global markets - The Asia-Pacific perspective. Journal of World Business, 48(2), 171-174.

Drori, G. S., Meyer, J. W., \& Hwang, H. (Eds.). (2006). Globalization and Organization: World Society and Organizational Change. Oxford: Oxford University Press.

Dunning, J., H. (2004 (1993)). The Globalization of Business. Abingdon, Oxon: Routledge.

Edwards, T., \& Kuruvilla, S. (2005). International HRM: national business systems, organizational politics and the international division of labour in MNC's. The International Journal of Human Resource Management, 16(1), 1-21.

Edwards, T., \& Kuruvilla, S. (2005). International HRM: national business systems, organizational politics and the international division of labour in MNCs. The International Journal of Human Resource Management, 16(1), 1-21.

Edwards, T., Sanchez-Mangas, R., Bélanger, J., \& McDonnell, A. (2015). Why are some subsidiaries of multinationals the source of novel practices while others are not? National, corporate and functional influences. British Journal of Management, 26(2), $146-162$.

Edwards, T., \& Tempel, A. (2010). Explaining variation in reverse diffusion of HR practices: Evidence from the German and British subsidiaries of American multinationals. Journal of World Business, 45(1), 19-28. 
Eisenhardt, K. M., Furr, N. R., \& Bingham, C. B. (2010). Micro-foundations of performance: Balancing efficiency and flexibility in dynamic environments. Organization Science, 21(6), 1263-1273.

European Working Condition Survey (EWCS; https://eurofound.europa.eu/european-working$\underline{\text { conditions-surveys-ewcs) }}$

Evans, P., Pucik, V., \& Björkman, I. (2011). Global Challenge: International Human Resource Management (2 ed.). New York: McGraw Hill.

Evans, P., Pucik, V., \& Björkman, I. (2017 (in press)). The Global Challenge: International Human Resource Management. New York: McGraw-Hill.

Farndale, E. (2005). HR Department Professionalism: A Comparison between the UK and other European Countries. The International Journal of Human Resource Management, $16(5), 660-675$.

Farndale, E., Paauwe, J., Morris, S. S., Stahl, G. K., Stiles, P., Trevor, J., \& Wright, P. (2010). Context-Bound Configurations of Corporate HR Functions in Multinational Corporations Human Resource Management, 49(1), 45-66.

Ferner, A. (2000). The underpinnings of 'bureaucratic'control systems: HRM in European multinationals. Journal of Management Studies, 37(4), 521-540.

Ferner, A., Tregaskis, O., Edwards, P., Edwards, T., Marginson, P., Adam, D., \& Meyer, M. (2011). HRM structures and subsidiary discretion in foreign multinationals in the UK. The International Journal of Human Resource Management, 22(03), 483-509.

Gerhart, B., \& Fang, M. (2005). National culture and Human Resource Management: Assumptions and evidence. International Journal of Human Resource Management, 16(6), 971-986. 
Goergen, M., Brewster, C., Wood, G., \& Wilkinson, A. (2012). Varieties of capitalism and investments in human capital Industrial Relations, 51(2), 501-527.

Greenwood, R., Oliver, C., Suddaby, R., \& Sahlin, K. (Eds.). (2008). The SAGE Handbook of Organizational Institutionalism. London: Sage.

Guillén, M. F. (2001). The limits of convergence. Globalization and organizational change in Argentina, South Korea and Spain. Princeton, Oxford: Princeton University Press.

Hall, P. A., \& Soskice, D. (Eds.). (2001). Varieties of Capitalism. The Institutional Foundations of Comparative Advantage. Oxford: Oxford University Press.

Henrich, J., Heine, S. J., \& Norenzayan, A. (2010). The weirdest people in the world? Behavioral and Brain Sciences, 33(2-3), 61-83.

Hippler, T., Brewster, C., \& Haslberger, A. (2015). The elephant in the room: The role of time in expatriate adjustment International Journal of Human Resource Management, 26(15), 1920-1935

Hofstede, G. H., Hofstede, G. J., \& Minkov, M. (2010). Cultures and organizations. Software of the mind: intercultural cooperation and its importance for survival (3 ed.). New York: McGraw-Hill.

House, R. J., Hanges, P. J., Javidan, M., Dorfman, P. W., \& Gupta, V. (Eds.). (2004). Culture, Leadership, and Organizations: The GLOBE Study of 62 Societies. Thousand Oaks, CAL.: Sage.

Jones, C., \& Massa, F. G. (2013). From novel practice to consecrated exemplar: Unity Temple as a case of institutional evangelizing. Organization Studies, 34(8), 1099-1136.

Knoben, J., \& Oerlemans, L. A. (2006). Proximity and inter-organizational collaboration: A literature review. International Journal of Management Reviews, 8(2), 71-89. 
Kostova, T., \& Roth, K. (2002). Adoption of an Organizational Practice by Subsidiaries of Multinational Corporations. Academy of Management Journal, 45(1), 215-233.

Krücken, G., \& Drori, G. S. (2009). World society: the writings of John W. Meyer. Oxford: Oxford University Press.

Lowe, K. B., Milliman, J., De Cieri, H., \& Dowling, P. J. (2002). International compensation practices: a ten- country comparative analysis. Human Resource Management, 41(1), 45-66.

Mayrhofer, W., Brewster, C., Morley, M., \& Ledolter, J. (2011). Hearing a Different drummer? Evidence of convergence in European HRM. Human Resource Management Review, 21(1), 50-67.

Mayrhofer, W., Müller-Camen, M., Ledolter, J., Strunk, G., \& Erten, C. (2002). The Diffusion of Management Concepts in Europe - Conceptual Considerations and Longitudinal Analysis. Journal of Cross-Cultural Competence \& Management, 3, 315-349.

McDonnell, A., Lavelle, J., \& Gunnigle, P. (2014). Human Resource Management in Multinational Enterprises: Evidence From a Late Industrializing Economy. Management International Review, 54(3), 361-380.

Michie, J. (Ed.) (2003). The handbook of globalisation. Cheltenham et al.: Elgar.

Mitchell, T., \& James, L. (2001). Building better theory: Time and the specification of when things happen. Academy of Management Review, 26(4), 530-547.

Moran, R. T., Harris, P. R., \& Moran, S. V. (2011). Managing cultural differences. Global leadership strategies for cross-cultural business success (8 ed.). Oxford: ButterworthHeinemann.

Morley, M., Heraty, N., \& Michailova, S. (Eds.). (2009). Managing Human Resources in 
Central and Eastern Europe London: Routledge.

Ohmae, K. (1995). The end of the nation state: the rise of regional economies. New York, NY et al.: Free Press.

Oliver, C. (1991). Strategic Responses to Institutional Processes. Academy of Management Review, 16(1), 145-179.

Paauwe, J. (2004). HRM and performance: Achieving long-term viability. Oxford: Oxford University Press.

Powell, W. W., \& Colyvas, J. A. (2010). Microfoundations of Institutional Theory. In R. Greenwood, C. Oliver, R. Suddaby, \& K. Sahlin (Eds.), The SAGE Handbook of Organizational Institutionalism (pp. 276-299). London: Sage.

Pudelko, M., \& Harzing, A.-W. (2007). Country-of-origin, localization, or dominance effect? An empirical investigation of HRM practices in foreign subsidiaries. Human Resource Management, 46(4), 535-559.

Rosenzweig, P. M., \& Nohria, N. (1994). Influences on Human Resource Management Practices in Multinational Corporations. Journal of International Business Studies, 25(2), 229-251.

Rugman, A., \& Verbeke, A. (2001). Subsidiary specific advantages in multinational enterprises. Strategic Management Journal, 22(3), 237-250.

Rugman, A. M., \& Oh, C. H. (2013). Why the home region matters: location and regional multinationals. British Journal of Management, 24(4), 463-479.

Rupidara, N. S., \& McGraw, P. (2011). The role of actors in configuring HR systems within multinational subsidiaries. Human Resource Management Review, 21(3), 174-185.

Sanders, K., Shipton, H., \& Gomes, J. F. (2014). Guest Editors' Introduction: Is the HRM 
Process Important? Past, Current, and Future Challenges. Human Resource Management, 53(4), 489-503.

Scott, W. R. (2003). Institutional carriers: reviewing modes of transporting ideas over time and space and considering their consequences. Industrial and Corporate Change, 12(4), 879-894.

Shen, Y., Demel, B., Unite, J., Briscoe, J. P., Hall, D. T., Chudzikowski, K., . . Zikic, J. (2015). Career success across 11 countries: implications for international human resource management. International Journal of Human Resource Management, 26(13), 17531778. doi:10.1080/09585192.2014.962562

Shipilov, A. V., Greve, H. R., \& Rowley, T. J. (2010). When do interlocks matter? Institutional logics and the diffusion of multiple corporate governance practices. Academy of Management Journal, 53(4), 846-864.

Thite, M., Wilkinson, A., \& Shah, D. (2012). Internationalization and HRM strategies across subsidiaries in multinational corporations from emerging economies-A conceptual framework. Journal of World Business, 47(2), 251-258.

Tung, R. L. (2016). New perspectives on human resource management in a global context. Journal of World Business, 51(1), 142-152.

Vaiman, V., \& Brewster, C. (2015). How far do cultural differences explain the differences between nations? Implications for HRM. The International Journal of Human Resource Management, 26(2), 151-164.

Welch, C. L., \& Welch, D. E. (2012). What Do HR Managers Really Do? HR roles on international projects. Management International Review, 52(4), 597-617.

Welch, D., \& Björkman, I. (2015). The Place of International Human Resource Management in International Business. Management International Review, 55(3), 303-322. 
Werner, S. (2002). Recent developments in international management research: A review of 20 top management journals. Journal of Management, 28(3), 277-305.

Whitley, R. (1999). Divergent capitalisms: The social structuring and change of business systems. Oxford: Oxford University Press.

Wood, G. T., Brewster, C., \& Brookes, M. (Eds.). (2014). Human Resource Management and the Institutional Perspective New York, Oxon: Routledge. 